\title{
Evaluation of purification procedures for DNA extracted from organic rich samples: Interference with humic substances
}

\author{
M. Harry, B. Gambier, Y. Bourezgui and E. Garnier-Sillam \\ Laboratoire de Biologie des Sols et des Eaux, Université Paris XII-Val de Marne, Avenue du Général de Gaulle, 94000 Créteil, France
}

\begin{abstract}
A limitation of the use of the Polymerase Chain Reaction (PCR) for soil DNA analysis is the contamination by humic substances. Numerous studies have been devoted to the elaboration of an effective purification method but none appears universal. During our investigations of soil bacterial changes induced by soil-feeding termites, we found that humic acid content usually impede DNA purification. Indeed, humic acids and nucleic acids share similar physicochemical properties. Here, we tested eight purification procedures including electrophoretical and chromatographical methods. The results show for DNA extracted from humic rich samples, e.g. termite mounds, that only the combination of two methods gave a DNA sufficiently pure to perform successful amplifications.
\end{abstract}

Our laboratory has focused attention for several years on the impact of tropical termites on physical and chemical soil properties and more specifically on the distribution of humic substances $[9,10]$. Our aim was to design molecular tools in order to study bacterial changes induced by termite activities. However, the samples of soil-feeding termite nests typically impede the purification of DNA because such nests are mostly made of termite dejections which are rich in organic matter and humic substances. Here we compare electrophoretic and chromatographic methods to purify DNA samples. The quality of DNA was then tested by performing amplification by Polymerase Chain Reaction (PCR). Considering physical and chemical properties of both DNA and humic substances, we also sought to explain how these molecules compete and interact during purification procedures.

\section{Material}

The samples originated from the rainforest of the NsimiZoetele region (South Cameroun). Termite mounds samples belong to the soil-feeding species Cubitermes subarquatus (Termitinae). Soils without termite activity were defined as controls. Termite mounds of $C$. subarquatus contain around $60 \%$ of clay, $45 \mathrm{mg} / \mathrm{g}$ of Total Organic Carbon (TOC) including $15 \%$ of humic acids. Control soils A2 $(2-5 \mathrm{~cm})$ and A6 $(100-140 \mathrm{~cm})$ have 44.4 and $67.4 \%$ of clay, 18.8 and $5.76 \mathrm{mg} / \mathrm{g}$ of TOC with $9 \%$ and $7 \%$ of humic acids, respectively. DNA extraction and purification were made in duplicate on termite mound and A2 samples. No DNA was noticeable in the A6 deeper strata. To test the efficiency of the procedures A2 and A6 sterilised subsamples were inoculated with a bacterial strain of Escherichia coli (Pharmacia, strain NM 522).

\section{DNA extraction}

The detailed procedure is described elsewhere [11]. Briefly, $0.4 \mathrm{~g}$ samples are submitted to a lysis solution containing lysozyme, proteinase K, and sodium dodecyl sulfate. Protein and cell debris were eliminated by a salting out using $\mathrm{NaCl}$. DNA was precipitated by isopropanol, dried and suspended 
in $20 \mu \mathrm{L}$ of ultrapure water. After the lysis procedure, all the DNA suspensions are coloured thus evidencing the co-occurrence of humic materials. All DNA samples were submitted to eight procedures of purification made in duplicate.

\section{Purification methods}

\section{Electrophoretical methods}

Two type of gels, agarose or polyacrylamide, were used to remove contaminants by molecular weight separation. First, low melting point (LMP) agarose gel (2\%) was used for electrophoresis at $4{ }^{\circ} \mathrm{C}$. Slices of agarose gel including the high molecular weight band of DNA was excised under ultraviolet illumination after ethidium bromide staining $(0.5 \mu \mathrm{g} / \mathrm{mL})$. Just before use for PCR amplification, the sample was heated at $80{ }^{\circ} \mathrm{C}$. A similar volume of ultrapure water was added in order to dilute the agarose particles. Then, after vigourous mixing, $1-2 \mu \mathrm{L}$ were added to PCR reaction preheating at $95{ }^{\circ} \mathrm{C}$. Second, polyacrylamide gel (3.5\%) was used in a vertical apparatus for electrophoresis $4 \mathrm{~h}$ at $250 \mathrm{~V}$ in $0.5 \times$ TBE $(89 \mathrm{mM}$ Tris, $89 \mathrm{mM}$ Borate, $2 \mathrm{mM}$ EDTA, $\mathrm{Ph}$ 8.3). After excision of the high molecular weight band of DNA, buffer (0.3M NaCl, $3 \mathrm{mM}$ EDTA, $30 \mathrm{mM}$ tris, $\mathrm{pH}$ 7.6) was added with a volume corresponding to the weight of the gel slice. After overnight incubation at $37{ }^{\circ} \mathrm{C}$ the samples were submitted to centrifugation (2000 g, $15 \mathrm{~min}$ ). The supernatant was then used for PCR.

\section{Minicolumn methods}

Three types of chromatography column have been experimented by using four kits: filled with gel filtration medium (Microspin S-200 HR), bind-resin (DNA cute, Eurobio; Wizard DNA clean-up System, Promega) and silica-gel membrane (QIAquick PCR purification Kit, Quiagen).

The Sephacryl gel filtration medium of the microspin columns is a porous gel that separate molecules according to size. Molecules larger than the largest pores of the swollen gel beads, those above the exclusion limit like DNA, cannot enter the gel and are thus eluted first. Smaller molecules enter the gel beads to various extent depending on their size and shape and are eluted with delay. Accordingly, the DNA could be eluted first and solely in our experiments using a short centrifugation.

For the DNA cute kit and the Wizard system, the resin used has a very high affinity for proteins but exhibits a very low affinity for nucleic acids at $\mathrm{pH}<7$. The resin was added to the DNA sample and the DNA was eluted by centrifugation (DNA cute) or mechanical pressure (Wizard system).

The QIAquick system uses a bind-wash-elute procedure for removing impurities from DNA samples. Samples were drawn through the silica-gel membrane by short centrifugation allowing nucleic acids to adsorb. Impurities were washed away, and pure DNA was eluted in a small volume of water. Noteworthy, the QIAquick and Wizard systems are optimised for DNA to 10 or 50 kilobases respectively. For improved recovery of native DNA the buffer of elution was heated at $80{ }^{\circ} \mathrm{C}$.

\section{Coupling method}

First, two types of minicolumns have been used successively, that is Wizard bind-resin (Promega) then QIAquick minicolumns (Quiagen). Second, electrophoretical method using LMP (Low melting Point) agarose was coupled with QIAquick silice-gel minicolumn. LMP slice gel was heated at $60{ }^{\circ} \mathrm{C}$ before introduction in the minicolumn.

\section{PCR amplifications}

The quality and stability of the purified DNA was tested by PCR on the day of purification, two days then ten days latter. In the meantime, samples were stored at $4{ }^{\circ} \mathrm{C}$. Bacterial primers were used to amplify a 590 base pairs fragment of $16 \mathrm{~S}$ ribosomal DNA. PCR amplifications were performed in a total volume of $25 \mu \mathrm{L}$. PCR primers and conditions were as previously described [11]. For each set of amplification we performed both a negative control using ultrapure water and a positive control using Echerichia coli DNA as templates. The PCR products were analysed by electrophoresis on a $0.8 \%$ agarose gel under UV light after an ethidium bromure staining.

\section{Results and discussion}

The purification of soil DNA was tested using eight methods. Four samples were analysed: two inoculated soils and two native soils, a tropical topsoil and nest-wall of a soilfeeding termite mound. We found that all extracted DNA samples are coloured. This result shows the co-occurrence of humic materials. The termite mound sample exhibited the darkest colour, whereas the A6 inoculated soil sample gave the lightest. Results on the quality of the purification and on the stability of the purified samples are reported in table I.

Using electrophoretical methods, PCR products of good intensity were obtained with low melting point agarose purification method even though DNA termite mound sample was diluted (1/10). However, PCR should be performed immediately after purification because of the low stability of the purified samples. The stability of the purified samples is higher using polyacrylamide gel though the amplifications showed a weak intensity for the DNA termite mound sample. Gel manipulation being not easy, the DNA recovery is smaller than that with LMP agarose procedure. Using these electrophoretical procedures it appears that DNA can often be well separated from humic substances. For samples showing high humic acids contents, e.g. termite mounds, some contaminants still persist after electrophoresis purification. This could be due either to the co-migration of humic acids 
Table I. Results of PCR amplification (A) and sample stability (S) by using DNA extracted from inoculated or native soils purified by eight procedures. (A +): obtention of PCR products of good quality, (A \pm ): PCR products of slight intensity, (A -): no PCR products. The stability of the purified sample is tested by submitting samples to PCR procedure the day of purification, two days and ten days latter. $\left(S_{+}\right)$: PCR products are obtained with the same intensity ten days after purification, $(S \pm)$ : PCR products are obtained with a lesser intensity ten days after purification, $\left(S_{-}\right)$: The obtention of PCR products the day of purification was not reproductible.

\begin{tabular}{|c|c|c|c|c|c|c|c|c|}
\hline \multirow{3}{*}{$\begin{array}{l}\text { PURIFICATION } \\
\text { Electrophoretical methods }\end{array}$} & \multicolumn{4}{|c|}{ INOCULATED SOILS } & \multicolumn{4}{|c|}{ NATIVE SOILS } \\
\hline & \multicolumn{2}{|c|}{ A2 $(2-5 \mathrm{~cm})$} & \multicolumn{2}{|c|}{ A6 $(100-140 \mathrm{~cm})$} & \multicolumn{2}{|c|}{ A2 $(2-5 \mathrm{~cm})$} & \multicolumn{2}{|c|}{ Termite mound } \\
\hline & & & & & & & & \\
\hline LMP agarose gel & $A+$ & $S \pm$ & $A+$ & $S+$ & $A+$ & S - & $A+{ }^{(1)}$ & S - \\
\hline Polyacrylamide gel & $A+$ & $S+$ & $A+$ & $S+$ & $A \pm$ & $S \pm$ & $A \pm$ & $S \pm$ \\
\hline \multicolumn{9}{|l|}{ Minicolumn methods } \\
\hline Porous gel (Pharmacia) & A - & & $A+$ & $S+$ & $A-$ & & $A-$ & \\
\hline Resine (Eurobio) & A - & & $A++^{(1)}$ & $S+$ & $A-$ & & $A-$ & \\
\hline Resine (Promega) & $A \pm$ & $S+$ & $A+$ & $S+$ & $A+(2)$ & & $A+{ }^{(3)}$ & \\
\hline Silica-gel membrane (Qiagen) & $A \pm$ & $S+$ & $A+$ & $S+$ & $A+(2)$ & & $A+(2)$ & \\
\hline \multicolumn{9}{|l|}{ Coupled methods } \\
\hline \multirow{2}{*}{$\begin{array}{l}\text { Resine (Promega) + Silica- gel } \\
\text { membrane (Qiagen) } \\
\text { LMP agarose + Silica-gel } \\
\text { membrane (Qiagen) }\end{array}$} & $A+$ & $S+$ & $A+$ & $S+$ & $A+$ & $S+$ & $A \pm$ & $S \pm$ \\
\hline & $A+$ & $S+$ & $A+$ & $S+$ & $A+$ & $S \pm$ & $A+$ & $\mathrm{S} \pm$ \\
\hline
\end{tabular}

(1) if samples are diluted at $1 / 10$, (2) if the procedure is repeated twice, ${ }^{(3)}$ if the procedure is repeated threefold.

and DNA molecules or to the formation of humic acid-DNA complexes before electrophoresis.

No PCR products were obtained for humic rich samples with the use of minicolumns filled with porous gel even after three elutions except for A6 inoculated soil DNA. Indeed, humic acids of high molecular weight did not enter the gel pores and were thus co-eluted with DNA (Fig. 1). Similar results were obtained with the use of DNA cute minicolumns filled with bind-resin. Only diluted A6 DNA extract gave PCR products. Using bind-resin Wizard column or silica-gel QUIAquick columns two or three procedures are required to perform successful PCR with rich humic samples that is native A2 soil and termite mounds. The conceptual model for the interaction of nucleic acids and humic acids with adsorption sites on clay minerals [12] could be adapted to silica gel membrane. Humic acids could compete with nucleic acids for adsorption sites. DNA molecules could also form complex which could be adsorbed. Therefore, DNA molecules, humic acids and humic acid-DNA complexes are eluted together (Fig. 2). Moreover, the competition between humic acids and DNA molecules is probably increased by the use of alkaline $\mathrm{pH}$ that induces the molecular stretching of humic acids [13]. When the procedure is repeated, contaminants are diluted resulting in the increasing number of free sites that improves the quality of the purification. Nonetheless, at each purification step a small amount of DNA is also lost.
The coupling of two methods gives a better purification of DNA. In this way, we obtained PCR products from termite mound DNA using successively minicolumns made with resin and silica gel membrane, but the sample stability is not optimal. Results are improved using LMP electrophoretical method followed by minicolunm filled with silica-gel membrane. The QUIAquick kit was preferred to the Wizard kit because with the latter resin molecules were

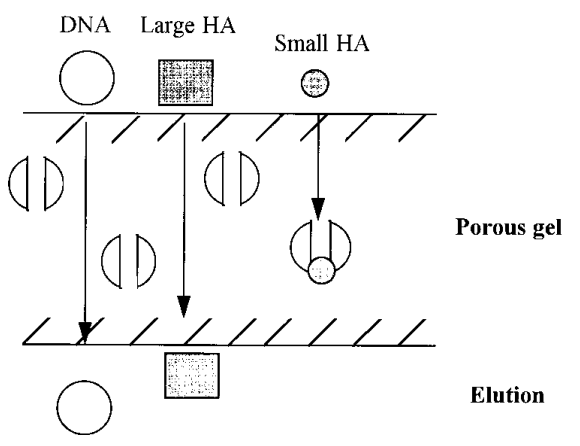

Figure 1. Explicative model for the persistence of humic acid (HA) contamination in DNA samples after purification procedure by using a porous gel (Sephacryl 200) as chromatography medium. 


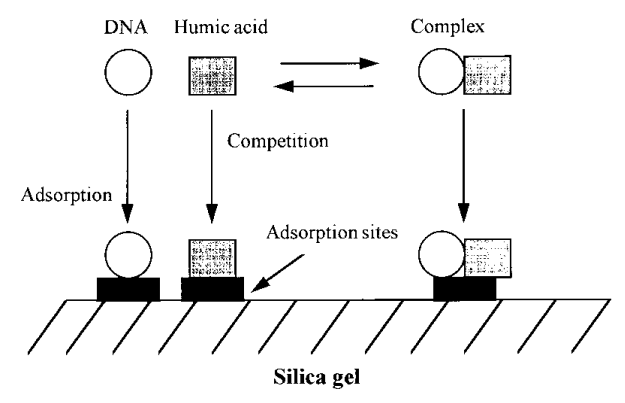

Figure 2. Explicative model for the co-occurrence of DNA and humic acids after purification procedure by using minicolumn with silica-gel membrane.

found in eluted DNA. This coupling method allows to remove impurities from humic rich samples. Indeed, during the first purification step a major part of humic substances is removed. During the second purification step the benefit is double: the agarose particles causing the low stability of purified samples are removed by the silica-gel membrane. Moreover, the silica gel membrane is enhanced by the low content of humic acids.

\section{Conclusion}

The purification of DNA from organic rich samples is impeded by the co-occurence of high molecular weight humic acids. Indeed, humic acids share physiochemical properties with nucleic acids. As outlined by some authors [6], it appears that no single method of purification will be appropriate for all soils and experimental designs. Here, we showed that the use of electrophoresis followed by microspin column give the purest DNA.

\section{References}

1. Tsai, Y.; Olson, B. H. Appl. Environ. Microbiol. 1992, 58, 2292-2295.

2. Ogram, A.; Sayler, G. S.; Barclay, T. J. Microbiol. Meth. 1987, 7, 57-66.

3. Holben, W. E.; Jansson, J. K.; Chelm, B. K.; Tiedje, J. M. Appl. Environ. Microbiol. 1988, 54, 703-711.

4. Knaebel, D. B.; Crowford, R. L. Mol. Ecol. 1995, 4, 579-591.

5. Porteous, L. A.; Seidler, R. J.; Watrud, L. S. Mol. Ecol. 1997, 6, 787-791.

6. Zhou, J.; Bruns, M. A.; Tiedje, J. M. Appl. Environ. Microbiol. 1996, 62, 316-322.

7. Purday, K. J.; Embley, T. M.; Takil, S.; Nedwell, D. B. Appl. Environ. Microbiol. 1996, 62, 3905-3907

8. Tebbe, C. C.; Vahjen, W. Appl. Environ. Microbiol. 1993, 59, 2657-2665.

9. Garnier-Sillam, E.; Harry, M. Ins. Soc. 1995, 42, 167-185.

10. Garnier-Sillam, E.; Renoux, J.; Toutain, F. Soil. Biol. Biochem. 1989, 21, 499-505.

11. Harry, M.; Jusseaume, N.; Gambier, B.; Garnier-Sillam, E. 1998, submitted to Soil Biol Biochem.

12. Sayler, G. S.; Nikbakht, K.; Fleming, J. T.; Packard, J. Soil Biochem. 1992, 4, 131-172.

13. Chen, Y.; Schitzer, M. Soil Sci. Soc. Am. J. 1976, 40, 682-686. 